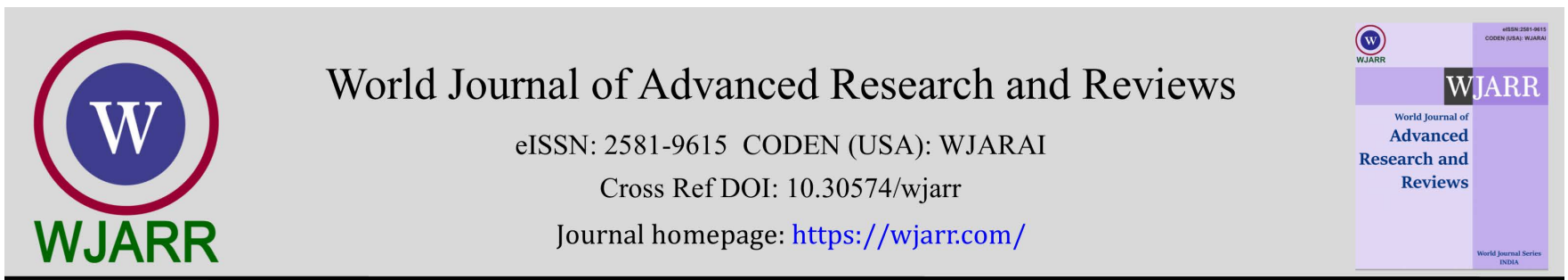

(RESEARCH ARTICLE)

\title{
Prevalence and predictors of under nutrition among adolescents in Tanahun District, Nepal
}

\author{
Ravi Kanta Mishra ${ }^{1,}{ }^{*}$ and Subekshya Thapaliya ${ }^{2}$ \\ ${ }^{1}$ Policy Planning and Monitoring Division, Ministry of Health and Population, Kathmandu, Nepal \\ ${ }^{2}$ Department of Nursing, Manmohan Memorial Institute of Health Science, Kathmandu, Nepal
}

World Journal of Advanced Research and Reviews, 2021, 09(01), 233-238

Publication history: Received on 01 January 2021; revised on 11 January 2021; accepted on 13 January 2021

Article DOI: https://doi.org/10.30574/wjarr.2021.9.1.0002

\begin{abstract}
Adolescent is the period of physical, psychological and social maturing from childhood to adulthood. The term adolescent refers to individuals between the ages of 10-19 years and the age group 15-19 years known as late adolescents. This study aims to identify the prevalence and predictors of under nutrition among the late adolescents in Tanahun District, Nepal. The study design was school based cross-sectional and conducted at 12 higher secondary schools of Tanahun district using multistage stratified sampling. The study applied the self-administered questionnaires and anthropometric assessment. The mean age of the adolescent was 17.43 years and two thirds were female. More than half of the respondents were janajatis followed by bhrahmin/chhetri and dalits. 18\% of the respondents were underweight. The mean weight and height of the respondent were $51.46 \mathrm{~kg}$ and $159.65 \mathrm{~cm}$. The mean BMI was calculated as 20.11 with SD 2.81. Sex of the adolescents, ethnicity and type of family was found to be associated with underweight. Having the milk/milk product which was two times more chances of having underweight those who drinks milk daily compare to those not having milk/milk product (OR 1.171, CI: 1.100-2.243). The daily of milk/milk product had a significantly associated with underweight by 1.44 times greater than those having milk/milk product. Those adolescents who were involves on any type of sports had 1.58 times more chances of having underweight than those not involved on sports activities (OR 1.587, CI: 1.114-2.262). The study found diverse results regarding under nutrition of adolescents in the study area. The present study indicates that nutritional status of adolescent is not satisfactory as one fifth of the adolescents were Undernourished. This study also focuses on some other contributing factors which may affect adolescent nutrition like socio-economic status, maternal working status, family type and family size, eating habits and personal habits. There is much scope for the improvement of their nutritional status. The most important predictors identified for underweight were adolescent's sex, cast and types of family $(p<0.05)$.
\end{abstract}

Keywords: Adolescent; Under Nutrition; Predictors; Body Mass Index

\section{Introduction}

Good nutrition is a prerequisite for the national development of countries and for the well-being of individuals [1]. Malnutrition in all forms is a major contributor to disease and early deaths for women and children. A child's nutritional future begins with the mother's nutritional status in adolescence and during pregnancy [2]. Adolescent is the period of physical, psychological and social maturing from childhood to adulthood. The term adolescent refers to individuals between the ages of 10-19 years and the age group 15-19 years known as late adolescents [3, 4]. Adolescent is a period of transition between childhood and adulthood. It is a significant period of human growth and maturation [5]. The classification of nutritional status is often interpreted according to the Body Mass Index (BMI). BMI serves as a simple and efficient indicator of different categories associated with body fat like underweight, overweight and obesity [6]. NDHS 2001 revealed that one in five girls of age 15-19 years had body mass index (BMI) below cut off point 18.5 i.e.

${ }^{*}$ Corresponding author: Ravi Kanta Mishra

Policy Planning and Monitoring Division, Ministry of Health and Population, Kathmandu, Nepal.

Copyright (C) 2021 Author(s) retain the copyright of this article. This article is published under the terms of the Creative Commons Attribution Liscense 4.0. 
under nutrition that has increased to 26.3 percentages in 2006 and nearly equal to 25.8 percentages in 2011 [1,7]. Adolescents in Nepal cover 23.45 percent of the total population that is nearly a quarter of population whereas they cover 22.34 percent of total population in Tanahun district [8]. Hence this study was attempted to document the prevalence and predictors of under nutrition among the adolescents.

\section{Material and methods}

Across sectional study was conducted in Tanahun district to determine the under nutrition among the higher secondary school adolescents [9]. The estimated sample size was 831 [10, 11]. The study applied the self-administered questionnaires and anthropometric assessment of the respondents. Data collection was done in between 26 Jan-15 Feb; 2016. Self-administered questionnaire was used to collect data. Weight and height of the adolescent was measured by using digital weighing machine and non-stretchable tape. Written consent was taken from the respondents.

BMI for age was calculated using growth chart developed by CDC using cut off value of 5th percentile for underweight. Coding and entry of data was done using EpiData 3.1 and analysis was done using SPSS 16.0 full version. Data analysis was done by frequency run and cross-tab. Bivariate and multivariate analysis were done in study to find out association between outcome and explorative variables. Odds ratio and corresponding $95 \%$ confidence interval was used to find out the significance of association. Variables which were found statistically significant during bivariate analysis were further analyzed using logistic regression model in multivariate analysis. Chi-square test was used to test goodness of fit of the logistic regression model. A methodological problem in this study was bias due to recall. The prevalence of under nutrition of adolescents were represented by height and weight i.e. BMI.

\section{Results and discussion}

The mean age of the adolescent was 17.43 years. Of total 831 respondents almost two thirds were female. Eighteen percent of the respondents were underweight. The mean weight of the respondent was $51.46 \mathrm{~kg}$. Similarly the mean height of the adolescent was $159.65 \mathrm{~cm}$. The mean BMI was calculated as 20.11 with SD 2.81. Sex of the adolescents, ethnicity and type of family was found to be associated with underweight. Underweight was found two times more likely on male rather than female ( $\mathrm{OR}=2.464, \mathrm{CI} 1.724-3.528)$. Those respondents who were from the advantaged group were found three times more likely to underweight than those adolescents who were from disadvantaged group (OR=2.846, CI: 1.987-4.076). Adolescent those were from the nuclear family had found two times more likely to underweight rather than those from joint family (OR=2.153, CI: 1.304-3.555).

Table 1 Demographic characteristics of the respondents

\begin{tabular}{|l|l|l|}
\hline Characteristics & Number $\mathbf{( N = 8 3 1 )}$ & Percentage \\
\hline Age of the respondents (in Years) & & \\
15 & 35 & 4.2 \\
16 & 121 & 14.6 \\
17 & 276 & 33.2 \\
18 & 252 & 30.3 \\
19 & 147 & 17.7 \\
Mean Age & $17.43 \pm 1.07$ & \\
\hline Sex of the respondents & & \\
Female & 540 & 65.0 \\
Male & 291 & 35.0 \\
\hline Ethnicity of the respondents & & \\
Dalits & 109 & 13.1 \\
Janajatis & 437 & 52.6 \\
Madhesi & 1 & .1 \\
Muslims & 4 & .5 \\
Brahmin and Chhetri & 251 & 30.2 \\
Others & 29 & 3.5 \\
\hline
\end{tabular}




\begin{tabular}{|l|l|l|}
\hline Marital status & 779 & 93.7 \\
Unmarried & 52 & 6.3 \\
Married & & \\
\hline Religion & 745 & 89.7 \\
Hindu & 59 & 7.1 \\
Buddhist & 3 & .4 \\
Islam & 24 & 2.9 \\
Christian & & \\
\hline Size of the family & 523 & 62.9 \\
$\leq 5$ members & 308 & 37.1 \\
$>5$ members & $5.50 \pm 1.77$ & \\
Mean size of the family & & 77.5 \\
\hline Type of family & 644 & 22.5 \\
Nuclear & & \\
Joint & 187 & \\
\hline
\end{tabular}

Table 2 Nutritional Measurement

\begin{tabular}{|l|l|l|}
\hline Nutritional status of the adolescents & Number (N=831) & Percentage \\
\hline Underweight & 152 & 18.3 \\
Normal Weight & 650 & 78.2 \\
Overweight & 23 & 2.8 \\
Obesity & 6 & 0.7 \\
Mean weight & $51.46 \pm 8.50 \mathrm{~kg}$ & \\
Mean Height & $159.65 \pm 9.53 \mathrm{~cm}$ & \\
Mean BMI & $20.11 \pm 2.81$ & \\
\hline
\end{tabular}

Table 3 Relationship of demographic information and underweight

\begin{tabular}{|c|c|c|c|c|}
\hline \multirow{2}{*}{ Characteristics } & \multicolumn{2}{|c|}{ Underweight } & \multirow[t]{2}{*}{$P$ value } & \multirow[t]{2}{*}{ OR $(95 \% \mathrm{CI})$} \\
\hline & $\begin{array}{l}\text { No } \\
\text { n (\%) }\end{array}$ & $\begin{array}{l}\text { Yes } \\
\text { n (\%) }\end{array}$ & & \\
\hline $\begin{array}{l}\text { Sex } \\
\text { Female } \\
\text { Male }\end{array}$ & $\begin{array}{l}468(86.7) \\
211(72.5)\end{array}$ & $\begin{array}{l}72(13.3) \\
80(27.5)\end{array}$ & $0.000^{*}$ & $\begin{array}{l}1 \\
2.464(1.724-3.523)\end{array}$ \\
\hline $\begin{array}{l}\text { Marital status } \\
\text { Married } \\
\text { Unmarried }\end{array}$ & $\begin{array}{l}43(82.7) \\
636(81.6)\end{array}$ & $\begin{array}{l}9(17.3) \\
143(18.4)\end{array}$ & 0.850 & $\begin{array}{l}1 \\
1.074(0.512-2.254)\end{array}$ \\
\hline $\begin{array}{l}\text { Ethnicity } \\
\text { Disadvantaged group } \\
\text { Advantaged group }\end{array}$ & $\begin{array}{l}481(87.3) \\
198(70.7)\end{array}$ & $\begin{array}{l}70(12.7) \\
82(29.3)\end{array}$ & $0.000^{*}$ & $\begin{array}{l}1 \\
2.846(1.987-4.076)\end{array}$ \\
\hline
\end{tabular}




\begin{tabular}{|c|c|c|c|c|}
\hline $\begin{array}{l}\text { Types of family } \\
\text { Joint } \\
\text { Nuclear }\end{array}$ & $\begin{array}{l}167(89.3) \\
512(79.5)\end{array}$ & $\begin{array}{l}20(10.7) \\
132(20.5)\end{array}$ & $0.003^{*}$ & $\begin{array}{l}1 \\
2.153(1.304-3.555)\end{array}$ \\
\hline $\begin{array}{l}\text { Mother's education } \\
\text { Illiterate } \\
\text { Literate }\end{array}$ & $\begin{array}{l}148(85.1) \\
531(80.8)\end{array}$ & $\begin{array}{l}26(14.9) \\
126(19.2)\end{array}$ & 0.199 & $\begin{array}{l}1 \\
1.351(0.853-2.139)\end{array}$ \\
\hline $\begin{array}{l}\text { Father's education } \\
\text { Literate } \\
\text { Illiterate }\end{array}$ & $\begin{array}{l}638(82) \\
41(77.4)\end{array}$ & $\begin{array}{l}26(14.9) \\
126(19.2)\end{array}$ & 0.199 & $\begin{array}{l}1 \\
1.351(0.853-2.139)\end{array}$ \\
\hline
\end{tabular}

$*_{\text {Significant at } p<0.05}$

The characteristics of this diversity include history of having the milk/milk product which was two times more chances of having underweight those who drinks milk daily compare to those not having milk/milk product (OR 1.171, CI: 1.1002.243). Regarding the association of daily frequency of milk/milk product had a significantly associated with underweight by 1.44 times greater than those having milk/milk product (OR 1.447, CI: 1.008-2.077). Those adolescents who were involves on any type of sports had 1.58 times more chances of having underweight than those not involved on sports activities (OR 1.587, CI: 1.114-2.262).

Table 4 Adjusted relationship of the characteristics with under weight

\begin{tabular}{|c|c|c|c|c|}
\hline Characteristics & Unadjusted OR & $P$ value & Adjusted OR & $P$ value \\
\hline $\begin{array}{l}\text { Sex } \\
\text { Female } \\
\text { Male }\end{array}$ & $\begin{array}{l}1 \\
2.464(1.724-3.523)\end{array}$ & 0.000 & $\begin{array}{l}1 \\
2.348(1.532-3.598)^{*}\end{array}$ & 0.000 \\
\hline $\begin{array}{l}\text { Ethnicity } \\
\text { Disadvantaged group } \\
\text { Advantaged group }\end{array}$ & $\begin{array}{l}1 \\
2.846(1.987-4.076)\end{array}$ & 0.000 & $\begin{array}{l}1 \\
2.604(1.774-3.823)^{*}\end{array}$ & 0.000 \\
\hline $\begin{array}{l}\text { Types of family } \\
\text { Joint } \\
\text { Nuclear }\end{array}$ & $\begin{array}{l}1 \\
2.153(1.304-3.555)\end{array}$ & 0.003 & $\begin{array}{l}1 \\
0.548(0.327-0.918)^{*}\end{array}$ & 0.022 \\
\hline $\begin{array}{l}24 \text { hours } \\
\begin{array}{l}24 \text { History of } \\
\text { having } \\
\text { product }\end{array} \\
\text { No } \\
\text { Yes }\end{array}$ & $\begin{array}{l}1 \\
1.571(1.100-2.243)\end{array}$ & 0.013 & $\begin{array}{l}1 \\
1.402(0.838-2.346)\end{array}$ & 0.199 \\
\hline $\begin{array}{l}\text { Daily intake of } \\
\text { milk/milk product } \\
\text { No } \\
\text { Yes }\end{array}$ & $\begin{array}{l}1 \\
1.447(1.008-2.077)\end{array}$ & 0.045 & $\begin{array}{l}1 \\
0.829(0.487-1.411)\end{array}$ & 0.489 \\
\hline $\begin{array}{l}\text { Sport Involvement } \\
\text { No } \\
\text { Yes }\end{array}$ & $\begin{array}{l}1 \\
1.587(1.114-2.262)\end{array}$ & 0.010 & $\begin{array}{l}1 \\
1.026 \\
1.574)\end{array}$ & 0.907 \\
\hline
\end{tabular}




\section{Discussion}

The prevalence of the underweight was found 18.3\%. A cross sectional study was conducted in Kaski district 2013, the prevalence of underweight was found to be $15.3 \%$ [11]. The prevalence of underweight was $25.8 \%$ among the late adolescent girls of cut off BMI value is 18.5 and $10.4 \%$ prevalence among the late adolescent girls of cut off BMI value is 17 [1]. But in this study the cut off vale for BMI was according to age for weight that is less than 5th percentile. Demographic and Health Surveys conducted in Ghana in 2008 the prevalence of underweight among 15-19 years of female in the survey was $13.8 \%$ [12]. The cross sectional study in Ethiopia shown that in-school adolescents (n = 348, 10-19 years old) the prevalence of thinness among adolescents was $26.1 \%$ [13]. Regarding the relationship of demographic characteristics with underweight, it was found that demographic factors viz, age of the adolescents, marital status, mothers' education and fathers' education of the respondents had no significant relationship with underweight. Similarly along with sex of the adolescents, ethnicity and type of family was found to be associated with underweight.

In the present study underweight was significantly more prevalent in boys than girls. Underweight was found two times more likely on male rather than female. Similar findings were reported by Anand et al among schools students in a village of Taridabad district in Haryana. [14] Venkaiah et al also reported the prevalence of underweight higher in boys (53\%) than girls (40\%) [15]. Sahabuddin et al [16] also reported that boys were affected more (75\%) than girls (59\%). Those respondents who were from the advantaged group were found 2.8 times more likely to underweight than those adolescents who were from disadvantaged group. Most of the respondents were janjatis and the purchasing power of janajati was high as high human development index [8] to their child. That might be a reason for most of the disadvantaged groups were nourished. Adolescent those were from the nuclear family had found two times more likely to underweight rather than those from joint family. In this study, paternal education was found insignificant with relation to underweight. Of various socio-economic characteristics, mothers' occupation, fathers' occupation, availability of own land and availability of domestic livestock had no significant relationship with underweight as previously reported [16-17].

The characteristics of this diversity include history of legumes, meat/fish, green vegetables and fruits but these had no significant relation with the underweight except having the milk/milk product which was two times more chances of having underweight those who drinks milk daily compare to those not having milk/milk product (OR 1.171, CI: 1.1002.243). Regarding the association of daily frequency of food i.e. daily intake of meat/fish, vegetables, fruits, eggs and Tiffin/lunch at school were not found significantly associated. But the daily of milk/milk product had a significantly associated with underweight by 1.44 times greater than those having milk/milk product (OR 1.447, CI: 1.008-2.077). Most of the personal habits i.e. smoking cigarette, drinking alcohol, slipping hours and regular exercise was found significantly associated with underweight except the sports involvement of the respondents. Those adolescents who were involves on any type of sports had 1.58 times more chances of having underweight than those not involved on sports activities (OR 1.587, CI: 1.114-2.262).

\section{Conclusion}

The study found diverse results regarding nutritional status of adolescents in the study area. The results of the present study indicate that nutritional status of adolescent is not satisfactory as more than one fifth of the adolescents are malnourished. This study also focuses on some other contributing factors which may affect adolescent nutrition like socio-economic status, maternal working status, family type and family size, eating habits and personal habits etc. There is much scope for the improvement of their nutritional status. The most important predictors identified for underweight were adolescent's sex, cast and types of family.

\section{Compliance with ethical standards}

\section{Acknowledgments}

We would like to thanks Prof. Shatrughan Ojha, Mr. Ravi Kumar Bhaskar and Dr Kumar Gaurav for their valuable guidance and support throughout the study period. We express our gratitude to District Heath Office and school principles for providing valuable information for the study. Similarly, we would like to thank Mr. Ravindra Mishra for his support during the study period. We would like to remember and thank all the respondents who gave their valuable time for interview. 


\section{Disclosure of conflict of interest}

There is no conflict of interest between the authors.

\section{Statement of ethical approval}

Ethical approval was obtained from the Institutional Review Board of National Medical College, Institute of Medicine, Tribhuwan University, Nepal. Formal permission was obtained from the District Education Office and schools which were selected for study in the Tanahun district.

\section{Statement of informed consent}

Individual written consent was also obtained from participants with a verbal explanation of the study, its purpose, and confidentiality.

\section{References}

[1] Ministry of Health and Population (MOHP) Nepal, New ERA, and Macro International Inc. Nepal Demographic and Health Survey 2011. Kathmandu, Nepal: Ministry of Health and Population, New ERA, and Macro International Inc., 2012.

[2] WHO Save the Children, Knowledge Summary: Women's and Child's Health- Nutrition Section. 2015

[3] Family Health Division, Department of Health Service, Ministry of Health and population, Implementation Guide on ASRH for District Health Managers. 2007.

[4] Ministry of Health, Department of Health Service, Family Health Division. National Adolescent Health and Development Strategy. 2000.

[5] Deshmukh P. R., Gupta S.S., Bharambe M.S., Dongre A.R., Maliye C, Kaur S and Garg B. S. Nutritional Status of Adolescents in Rural Wardha. 2006, Indian Journal of Pediatrics, Volume 73.

[6] Raut B. K. et al.: Determination of Risk Factors Associated with Childhood Obesity and the Correlation with Adult Obesity- A Random Cross Sectional Study from Nepal. American Journal of Health Research, 2014; 2(4): 134-139 Published online August 20, 2014 (http://www.sciencepublishinggroup.com/j/ajhr)

[7] Ministry of Health and Population (MOHP) [Nepal], New ERA, and Macro International Inc. Nepal Demographic and Health Survey 2006. Kathmandu, Nepal: Ministry of Health and Population, New ERA, and Macro International Inc., 2007.

[8] Government of Nepal, Central Bureau of Statistics. Major Finding of Centre Bureau of Statistics report. 2011.

[9] Ministry of Education, District Education Office. List of Higher Secondary school in Tanahun District, 2068.

[10] Daniel WW. Biostatistics, A foundation for Analysis in the Health Sciences. Wiley India Pvt. Ltd. 7th ed. 2007; 183.

[11] Acharya B and et. al. Prevalence and socio-demographic factors associated with overweight and obesity among adolescents in Kaski district, Nepal. Indian journal of community health / vol 26 / supp 02 / dec 2014;118-22.

[12] Doku D. T, Neupane S. Double burden of malnutrition: increasing overweight and obesity and stall underweight trends among Ghanaian women. BMC Public Health 2015; 15:670

[13] Melaku YA, Zello GA, Gill TK, Adams RJ, Shi Z. Prevalence and factors associated with stunting and thinness among adolescent students in Northern Ethiopia: a comparison to World Health Organization standards. Archives of public health = Archives belges de santepublique. 2015;73:44.

[14] Anand K, Kant S, Kapoor SK. Nutritional status of adolescent school children in rural North India. Indian J Paediatr. 1999;36:810-5.

[15] Venkaiah K, Damayanti K, Nayak MU, Vijayraghavan K. Diet nutritional status of rural adolescents in India. Eur J ClinNutr. 2002;56:1119-25.

[16] Shahabuddin AK, Talukdar K,Talukdar MK, Hassan M, Seal A,et al. Adolescent nutrition in a rural community in Bangladesh. Indian J Paediatr. 2000;67:93-8.

[17] Pauline M, Selvam S, Swaminathan S, Vaz M. Body weight perception is associated with socio-economic status and current body weight in selected urban and rural south Indian school-going children. Public Health Nutr. 2012 Dec;15(12):2348-56. doi: 10.1017/S1368980012000134. 